流涙を初発症状とした篩骨洞骨腫例

\author{
韓 相善・北村 溥之・宮田 耕志 \\ 金子賢一・安里亮・平野滋
}

\title{
Ethmoid Osteoma Causing Epiphora; A Case Report
}

\author{
Sanson Han, Hiroyuki Kitamura, Kouji Miyata, \\ Keni-chi Kaneko, Ryo Asato and Shigeru Hirano \\ (Tenri Hospital)
}

There have not been many reports of ethmoid osteomas in the Japanese literature. The most commonly described symptons are facial pain and headache. We recently treated a patient with ethmoid osteoma causing epiphora by compression of the lacrimal sac.

She was 60 years old and complained of left epiphora. We diagnosed ethmoid osteoma on the basis of X-ray and CT scan findings. The epiphora was completely relieved by removal of the osteoma compressing the lacrimal sac.

Key words: osteoma, ethmoid sinus, epiphora

はじめに

鼻副鼻腔領域に発生する良性腫瘍の中で, 骨 腫は決して稀な疾患ではないが，本邦での報告 例は多くない。今回我々は流涙を初発症状とし て発症した篩骨洞骨腫の 1 例を経験したので, 若干の文献的考察を加えて報告する。

\section{症例}

患者 : 60歳, 女性.

\section{主訴：左流涙.}

既往歴: 20 歳時隆鼻術.

家族歴：特記すべきことなし.

現病歷: 平成 4 年 4 月頃より左流沪を自覚し, また左内眼角部に圧痛のない硬い腫瘤を触知し たため, 同年 9 月 14 日当院眼科を受診した.

CT 上, 左篩骨洞から涙骨にかけての腫瘤が認 められたため，9月28日当耳鼻咽喉科へ紹介さ
れた。

初診時所見 (図 1)：左内眼角部に径 $8 \mathrm{~mm}$ の 骨性硬, 境界明瞭, 可動性なく圧痛のない腫瘤 を触知した。鼻内所見として軽度の肥厚性鼻炎 を認めるのみで, 複視や眼底の異常所見などは 認めなかった。

単純鼻X線, 断層写真(図 2): 左篩骨洞を中 心にして拇指頭大の境界明瞭な円形陰影を認め た。

CT 写真 (図 3)：左篩骨洞から涙骨にかけて bone density mass を認めた.

99m Tc-MDP シンチ (図 4) : 腫瘤に一致して 99m Tc-MDP が高濃度に集積していた。

入院後経過 : 以上より左篩骨洞骨腫と診断し, 入院の上, 平成 4 年 12 月 10 日全身麻酔下に左鼻 外穊骨洞手術を施行した. 腫瘤は沃囊の後壁か 


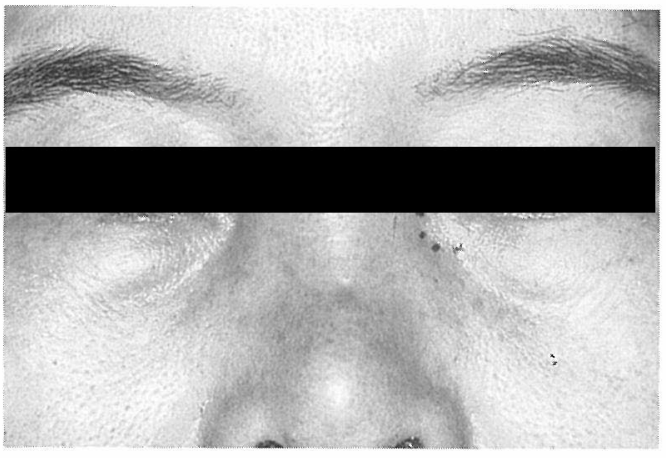

図 1 初診時所見

左内眼角部に径 $8 \mathrm{~mm}$ の腫瘤を認める.

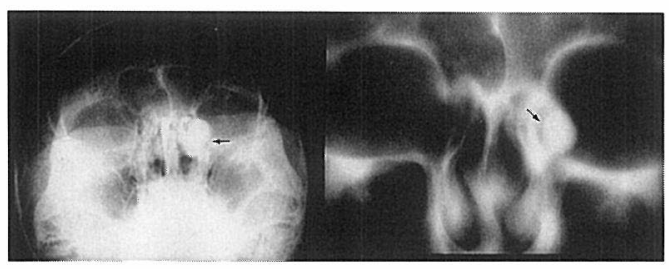

図2 左: 単純鼻X線像 右 : 上顎断層 X線像 左笁骨洞に骨腫様陰影(矢印)を認める.

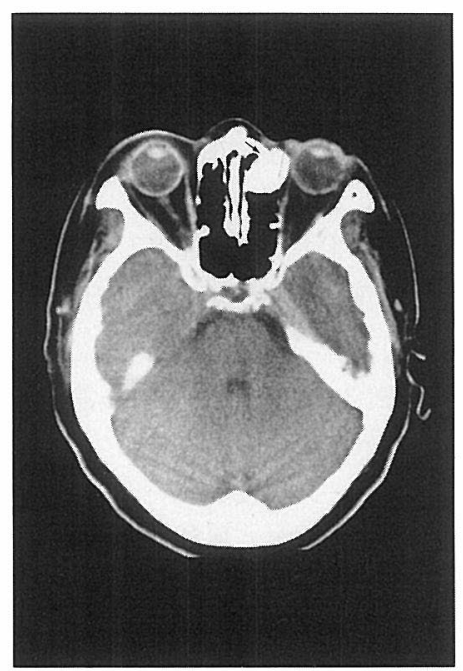

図 3 冠状断 CT 像

左篩骨洞に bone density mass (矢印)を認め る.
ら沃留内に突出していた。上顎骨前頭突起を鉗 除し，篩骨洞を開放後，腫瘤を全摘出すること ができた(図 5).

摘出標本 (図 6 ) : 径 $28 \times 22 \times 13 \mathrm{~mm}$, 骨性硬,

図 4 Tc シンチ像

腫瘤に一致して ${ }^{99 \mathrm{~m}} \mathrm{Tc}-\mathrm{MDP}$ が高濃度に集積 している.

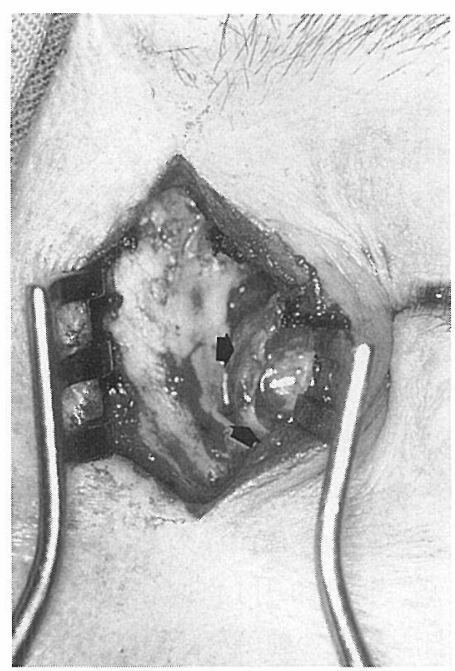

図 5 術中所見

沃翼を切断し，腫瘤 (矢印)を明視下に拈いたと ころ. 
不整形で重量は $7 \mathrm{~g}$ であった。

病理組織像（図 7)：豊富な骨梁からなる成熟 骨組織で形成されて扮り，硬性骨腫との診断で あった。

術後10日目で退院し，30日目に術時，鼻涙管 から鼻腔へ插入したシリコンチューブを抜去し， 現在流涙も止及経過良好である。

\section{考察}

鼻副鼻腔領域に発生する良性腫瘍の中で，骨 腫は最も多いとされ，その頻度は Childrey ${ }^{1)} に$ よると無作為に選んだ3510例の副鼻腔X写真で 15 例 $(0.43 \%)$ の骨腫を発見し，本邦では大谷

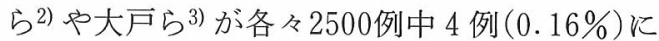
認められたと報告している。

発生部位として欧米では前頭洞，篩骨洞，上

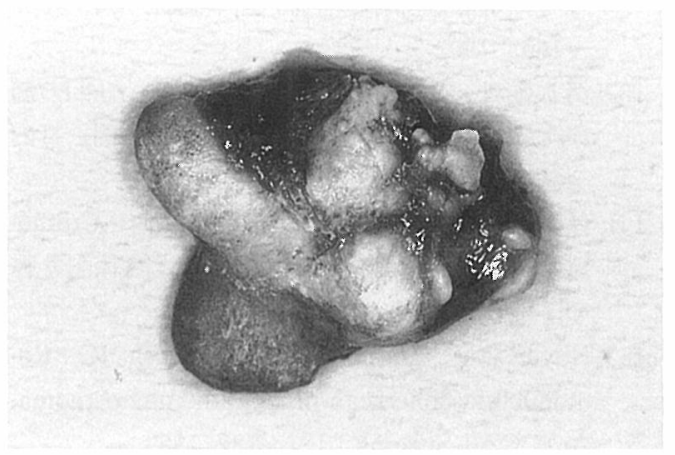

図 6 摘出標本

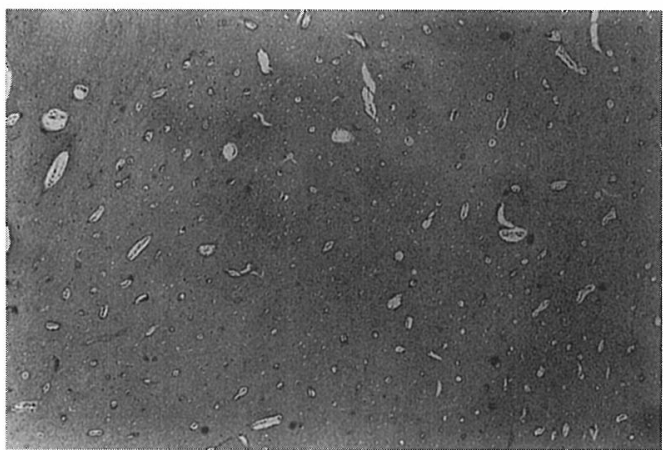

図 7 病理組織像

豊富な骨梁からなる成熟骨組織で形成されている $(\mathrm{HE} \times 400)$.
顎洞，蝶形骨洞の順に多いのに対し，本邦では 篩骨洞が最も多いとされている。午の相違とし て，北村ら4)は日本人の前頭洞の発育が悪いた めと述べ，また神尾5) は単純鼻 X線の及では前 頭洞原発か篩骨洞原発か区別しにくい場合があ り得ると指摘している。

好発年齢は10代から30代に多いとされ，性別 では, Hallberg ら ${ }^{6)}$ やSamy ら7) は男性が女性 の 2 倍近く発生していると報告しているのに対 し，北村ら 4) は男女差はなかったとしている。

症状は浮とんどない場合が多く, 腫瘍が増大, 進展するにつれて種々の症状を呈するようにな る8) 12). 眼窩方向へ進展した場合, 眼球突出, 視力障害が出現するが，本症例の場合，沃褧を 圧迫したためと考兄られる流涙が生じている。 鼻副鼻腔方向へ進展した場合，副鼻腔炎や，洞 自然孔の閉塞による mucocele や pyocele が生 じ，頭痛や前頭部頉部腫脹が生じてくる．更に 頭蓋内に進展すると髄液漏，髄膜炎，脳膿瘍な ぞを併発し，片麻痺やてんかん様発作などをき たした報告13) も認められる。

骨腫の発生原因としては,

1 ）前頭洞骨結合部の軟骨遺残からの発生説

2 ）胎生期胚芽迷入説

3 ) 炎症説, 外傷説

などが挙げられている，本例も過去に隆鼻術を 施行されて扣り，それが何らかの影響を及淁し た可能性も考兄られる.

病理組織学的には

1 ）硬性骨腫 : 硬く密な骨組織よりなり Havers 氏管と少量の結合組織を含む。

2 ）海綿状骨腫：層状構造をもち密な骨組織 を欠き海綿状組織よりなる。

3 ）混合性骨腫：上 2 者が混在する. に分類される.

診断としては，X線写真が最も簡便で有用で あるが腫瘍の進展程度を判定するには CT が役 立つ。

治療法は外科的切除が第 1 であり，その方法 として lateral rhinotomy, Killian 氏法，萩野氏 
法などがあるが，最近では美容上，あるいは頭 蓋内進展のため前頭開頭術を用いることもあ る14)。しかし腫瘍が再発や悪性化する事もな いので，小さい場合は症状が発現しない限り $\mathrm{X}$ 線像で経過観察を続け，症状が発現したり，腫 瘍の増大が認められた場合にの及摘出術を施行 すれば良いと考える。また最近では Tc シンチ により骨腫の増殖性を判定できるといら報告 ${ }^{15}$ も認められる.

$$
\text { まとめ }
$$

今回我々は，沃囊の圧迫による流涙を初発症 状とした篩骨洞骨腫の 1 例を経験し，外科的切 除により良好な結果を得た例を報告した。

稿を終えるに当たり，御校閱を賜りました京都大 学耳鼻咽喉科学教室本庄 撖教授に深謝いたします。

本論文の要旨は第247回日耳鼻大阪地方連合会 (平 成 5 年12月，大阪市) に执いて口演した。

\section{参考文献}

1) Childrey JH : Osteoma of the sinuses, the frontal and the sphenoid bone. Arch Otolaryng $30: 63,1939$.

2）大谷 嚴, 佐藤三郎, 服部政夫, 他 : 前頭洞骨 腫の 3 症例. 耳喉 $39: 837 \sim 843,1967$.

3）大戸武久, 内田 豊, 堀内博人, 他 : 視力障害 をきたした巨大なる穊骨洞骨腫症例について。 耳展 $22: 577 \sim 582,1979$.

4）北村達也，皆藤彦義，本多芳男：巨大なる鼻副 鼻腔骨腫の 1 症例. 耳展 $30: 377 \sim 381,1987$.

5）神尾友彦：前額洞飞発生し, 眼窩, 篩骨蜂窩, 蝴蝶洞を埋めたる骨腫に就て。大日耳鼻 45 ： 197, 1939.
6) Hallberg OE and Begley JW : Origin and treatment of osteoma of the paranasal sinuses. Arch Otolaryng 51 : 750 760, 1950.

7) Samy LL and Mostafa H : Osteoma of the nose and paranasal sinuses with a report of twenty one cases. J Laryngol Otol 85 : 449 469, 1971.

8）堤内邦彦, 小川 明, 吉積 隆, 他 : 笁骨洞骨 腫の 1 例. 耳喉 $53: 463 \sim 466,1981$.

9）前田秀彦, 石塚洋一, 名越好古, 他: 副鼻腔骨 腫の 3 症例. 耳展 $28: 179 \sim 184,1985$.

10）过 純, 西山正司, 木村 正, 他: 前笁骨神 経由来の頭痛を来した前頭洞骨腫. 耳鼻臨床 $80: 1071 \sim 1074,1987$.

11）宇山啓子, 館野秀樹：慢性副鼻腔炎を伴った篩 骨洞骨腫の 1 症例. 耳喉頭頸 $62: 827 \sim 830$, 1990.

12）滝元 徹, 伊藤 真, 嘉藤秀章 : 頭痛の原因と なった小さな篩骨洞骨腫，耳鼻臨床 $85: 1599$ $\sim 1602,1992$.

13）清水雄三, 樋口治之, 中島一夫, 他 : 3 回の䯣 膜炎症状を発症した篩骨洞部骨腫の 1 例. 日内 会誌 $76: 1141,1987$.

14）辻 富彦，金子省三，真崎正美，他：Craniofacial approach にて摘出した巨大篩骨洞骨腫 の 1 例. 耳展 $35: 387 \sim 392,1992$.

15) Noyer AM, Chapuik JS and Kirsh JC : Radionuclide bone scan in frontal sinus osteoma. Aust NZ J Surg $59:$ 127 132, 1989.

原稿受付: 平成 6 年 1 月 4 日 原稿採択: 平成 6 年 2 月 14 日 別刷請求先 : 韓 相善 干632 天理市三島町 200 天理よろつ”相談所病院耳鼻咽喉科 